Thematic Article

\title{
Labour Market Characteristics of Helping Professionals
}

\author{
Cintia Csók ${ }^{1}$ \\ Recommended citation: \\ Csók, C. (2020). Labour Market Characteristics of Helping Professionals. Central European Journal of Educational \\ Research, 2(1), $66-75$.
}

\begin{abstract}
In Hungary, considerable efforts have been made in recent years to analyse the career paths of higher educational graduates, which have highlighted the need for field-specific and training-specific analysis. In this context, our research concentrates on a special training segment, focusing on the position of young professionals working in occupations helping the function of the society. Previous research focused only on the professionalization of the different occupations and the recruitment was examined from institutional and regional aspects. However, during the statistical analysis we examined the social recruitment base and the labour market situation of social pedagogy graduates in the Graduates 2012 (Frissdiplomások 2012) national database. The novelty of our work lies in the comparison of those who graduated in social work, pedagogy and andragogy in full-time programs. The most important result of our quantitative analysis is the statement that the differences in the composition of the group are strongly explained by the regional location of the institutions providing the training. In terms of horizontal and vertical congruence, the values of the humanities group are the most unfavourable.
\end{abstract}

Keywords: helping professions; higher education; social recruitment; labour market

\section{Introduction}

In Hungary, after the political transition, the massification of higher education started (Kertesi \& Köllő, 2006; Csók, 2020a), as a result of which the operation of the institutions was fundamentally changed. Accordingly, the cultural and social composition of the students changed, and the expectations of the labour market for young people also increased (Hrubos, 2011; Pusztai, Bocsi \& Ceglédi, 2016; Csók, 2020a). At the same time, a kind of structural metamorphosis could be observed in the field of human services. In addition to the state, the role of the civil sector, a type of private sector, however functioning for public purposes, has been increased that has long been involved in the management of social problems at international level (Márkus, 2016; Csók, 2020a). With the development of human services, the differentiation of helping professions has begun (Molnár, 2014; Csók, 2020a).

Higher educational trainings preparing for helping professions have long enjoyed great popularity. However, based on the data of recent years, it seems that applicants for higher education have become uncertain about their further education decisions (Csók, 2020a). Research also draws attention to the contradictions between the social demand for professionals and the low capacity of the students to be recruited, the decreasing funding (especially in the case of expensive practical training), the problems in employment and the contradictions between the content of the training and the applicability of the acquired knowledge and skills in a given job (Temesváry, 2010; Balogh et al., 2015; Csók, 2020a).

1 University of Debrecen, Debrecen, Hungary; csokcintia@gmail.com 
The relevance of choosing the topic is demonstrated by the fact that the judgment of the social function, usefulness and necessity of helping professions is the subject of debate. The question arises as to the place and role of these qualifications in the labour market, especially in a disadvantaged region. However, the social utility of professions can only be interpreted in conjunction with the training (Budai, 2014; Csók, 2020a).

The academic achievement and social integration of the growing generations are supported by several professionals. Some of the helping professions work specifically for this, while the other half deals with the opportunities of catching up with disadvantaged social groups (Csók, 2020a; Csók, 2020b). Our research focuses on the social recruitment basis of the full-time social pedagogy training (Csók, 2020b) and on the labour market characteristics of fresh graduates. Our choice of the topic is justified by the fact that the expansion of this program, as a gap-filling training, started at the same time as the expansion and diversification of higher education (Benkő, 2009; Csók, 2020b). Nevertheless, little research was done in Hungary that would comprehensively analyse the results of a career tracking research concerning social pedagogy professionals (N. Tóth, 2011; N. Tóth, 2014; Csók 2020b). The novelty of our work allows us to examine graduates of social work, pedagogy and andragogy full-time programs for comparison. Regarding these, it is common that, although mostly in different areas and at different stages of life, all four professions perform a social assistance function. Furthermore, they have a special ability to come up with solutions to the problems in innovation and modification of individuals and communities (Kleisz, 2005; Csók, 2020a; Csók, 2020b).

\section{Methodology}

In the spring of 2012, 32 higher education institutions gathered data in the framework of the Hungarian Graduate Career Tracking System (DPR) using online questionnaires ${ }^{2}$ about the individuals graduating one, three and five years before. The staff of the Higher Education Department of Educatio Non-profit LLC (Educatio Nonprofit Kft.) created the national database, Graduates 2012 (Frissdiplomások 2012) database, from institutional data, and as a result of the weighting procedure, a representative population was formed according to gender, year of graduation, training field, training level and schedule. The total number of respondents was 24,890 (Veroszta, 2013; Csók 2020b). The numbers of full-time bachelor/traditional trainings investigated in our study are the following: social pedagogy $\mathrm{N}=127$, social work $\mathrm{N}=192$, pedagogy $\mathrm{N}=59$ and andragogy $\mathrm{N}=184$. During the analyses, the two training courses belonging to arts and humanities (pedagogy and andragogy) we merged ${ }^{3}(\mathrm{~N}=243)$, which create the three assistant profession groups. Regarding the total sample size (N_total=562), 32.4\% of the respondents started their studies in the traditional form of training and $67.6 \%$ in the new multi-cycle training system (BA) (Csók, 2020b).

It should be noted that Kiss (2015), besides the benefits of DPR surveys (it provides the largest and most appropriate sample concerning the relationship between the higher education and the labour market in Hungary to draw appropriate conclusions), points out the limitations as well (possible distortions caused by the self-selection mechanism, the generalisation of the results is limited) that should be kept in mind during interpretations.

Analysing the Graduates 2012 database, the social recruitment of the graduates of helping professions was examined, which could be tested with the following indicators followed by Fónai (2010): the educational level of the parents, the relationship between qualifications and/or occupation of the parents and grandparents and those of the asked individuals, and the type of settlement of the student place of habitation. According to Kiss (2013), this can be supplemented with a subjective indicator thus with the judgment of the financial situation of the family at the age of 14 (Csók, 2020b). We also analyse the labour market characteristics of the graduates, including the transition from

\footnotetext{
2 The central questionnaire block prepared for graduates in 2012 can be viewed and downloaded: https://www.felvi.hu/felsooktatasimuhely/dpr/online kerdoivek/online kerdoivek 2012 tavaszi felmeres

${ }^{3}$ Merging the two fields is confirmed by the low number of items of the pedagogy bachelor course and the belonging to the same field of education. However, in a later research, we consider it necessary to analyse the data tables separating andragogy and pedagogy bachelors.
} 
higher education to the world of work and the current labour market situation at the time of the study.

The database of 2012 was chosen as it contains data on the trainings being examined in a larger number, which is probably related to the high proportion of graduates of these programs in the given period, in contrast to the significant decrease in recent years (Csók, 2020b). The analysis was done with IBM SPSS Statistics 20 program using the following statistical methods: percent calculation, average calculation, cross-table analysis (chi-square test) and partial correlation analysis.

\section{The recrutation basis of the helping professions}

According to sociological studies, the social recruitment base of the various trainings is different, and students from families with lower social status may also choose career paths promising more modest career opportunities (Nagy, 2008; Benkő, 2009; Csók, 2020b). This tendency is particularly characteristic for higher educational institutions of disadvantaged regions, where the dominance of lower status students is mostly observed in terms of student composition (Teperics, 2005; Pusztai, 2006; Koucký quotes Pusztai, 2011). In addition, social recruitment has a strong correlation with the status of a profession, thus it can be appropriate to describe their situation (Fónai, 2010). Previously, it has been summarised that the social recruitment of students can be analysed along with four indicators according to Fónai (2010) and Kiss (2013). However, during our examinations, we obtained significant results only for the educational level of the parents $(\mathrm{p}<0.05)$, thus, concerning validity, we provide the relevant data and the other three is not manifested.

A generally valid correlation can be seen between the decision-making of the students and the academic achievement of the students, which is mostly determined by the educational level of the parents (Róbert, 2000; Pusztai, 2015). In this database, the aggregated data of the educational level of the parents were regarded, created according to the model of Róbert (1986). ${ }^{4}$ Research on social pedagogy professionals, and those directed for social professionals in the broader sense show that the profession is primarily attractive to the children of non-graduate parents (Nagy, 2008; Benkö, 2009). These results are also claimed by our research, as according to the data of Table 1, the distribution of parents with a quasi-primary level qualification $(46.7 \%)$ is overrepresented among social pedagogy graduates (Adj.Resid.=2.8). The proportion of parents with quasi-tertiary educational level is the highest among social workers (20.3\%), followed by andragogy and pedagogy BA graduates $(16.9 \%)$, and the group of social pedagogy graduates $(9.1 \%)$. Compared to national data, the proportion of parents with tertiary educational level can be considered very low in the examined groups. According to the DPR analyses of Gáti (2010), the distribution of graduate parents is the highest in the following fields of education: law and administration $(56 \%)$, medical and health sciences $(56 \%)$, economics $(51 \%)$, informatics $(49 \%)$ and natural sciences $(48 \%)$. Compared to our results, the values of the certain fields of education in social sciences (45\%) and humanities (44\%) also have more favourable indicators. As an explanation, it can be mentioned that parents who are at a higher level in the hierarchy of income and authority would like their children to be able to reproduce the social situation that describes them. As a result, careers providing lower income and prestige that are the subject of our current research are less attractive to the children of the parents with higher qualification (Benkő, 2009; Csók, 2020b). All this has to be emphasized as the social stratification field has an influence on school career school as well as on the future perceptions related to employment and work (Pusztai, 2015; Csók, 2020b).

\footnotetext{
4 Qualifications: primary (up to 8-class primary education, vocational/technical schools without GCSE), secondary (secondary vocational school/ secondary technical school, secondary grammar school), tertiary (college, university/academic degree). An average was calculated based on the codes of the educational level of the father and mother. In the case of the same level of the parents, the same code was given while in case of difference, the lower value was given on the basis of the decision of the researcher.
} 
Table 1. The merged educational level of the parents (\%). Source: Graduates 2012.

\begin{tabular}{cccc}
\hline & $\begin{array}{c}\text { Social pedagogy } \\
\text { graduates } \\
(\mathrm{N}=127)\end{array}$ & $\begin{array}{c}\text { Social work } \\
\text { graduates } \\
(\mathrm{N}=192)\end{array}$ & $\begin{array}{c}\text { Andragogy and } \\
\text { Pedagogy BA } \\
\text { graduates } \\
(\mathrm{N}=243)\end{array}$ \\
\hline Quasi primary level & $\underline{\mathbf{4 6 , 7}}$ & 35,2 & 30,9 \\
\hline Quasi secondary level & 44,2 & 44,5 & 52,2 \\
\hline Quasi tertiary level & 9,1 & 20,3 & 16,9 \\
\hline Total & $\mathbf{1 0 0}$ & $\mathbf{1 0 0}$ & $\mathbf{1 0 0}$ \\
\hline
\end{tabular}

The correlation was significant at $\mathrm{p}<0.05$ level $(\mathrm{p}=0.012)$. In the case of the underlined values, the absolute value of the adjusted residual is higher than two.

Partial correlation analysis was applied to interpret the data. In our study, focusing on the created career groups, the supply is complete in four training institutions (University of Debrecen, University of Pécs, University of Szeged, Szent István University), although it does not correlate with the selection based on the educational level of the parents, even it is outstandingly characteristic in the studied faculties. According to our more thorough analysis at the institutional level, the impact of the recruitment basis of the institutions seems to be more important. In accordance with our results, based on Hegedüs (2016) data on Felvi (Higher Education Admission) database, it was found that the location of the institution and the premises significantly affects the proportion of disadvantaged students. All in all, young professionals have come from families with lower social status, and the differences in the composition of the groups reflect the regional location of the institutions providing the training.

\section{The transition from higher education to work}

$80.8 \%$ of the freshly graduated social pedagogy professionals who participated in the study were searching for work directly after reaching the final certificate, while $12.0 \%$ were already working before reaching the final certificate. Those who were not looking for work directly for other reasons $(5.6 \%)$ were justified the decision by the following: travelling abroad, voluntary work, privacy reasons, illness or he/she was employed immediately by the institution of the last field exercise. However, among the three graduate groups, social workers had the highest proportion of those working before the final certificate $(17.7 \%)$ the most characteristic option was the continuation of studies while in the case of graduates of arts and humanities (24.3\%) (Adj.Resid.=6.5).

Furthermore, the characteristics of those graduates who were looking for work immediately after receiving the final certificate $\left(\mathrm{N}_{-}\right.$total $\left.=379\right)$ are presented. The fresh graduate job-seeker social pedagogy professionals $(\mathrm{N}=101)$ applied for jobs at an average of 30 employers during the job search, and they were invited to job interviews or contacted in some other form on an average of five times. After obtaining the final certificate, $20.8 \%$ of them were immediately employed within one month. $61.4 \%$ of the respondents needed a longer period of time to find their first job which meant four months (4.45) on average. These results are in accordance with the data of all job-seeking graduates in the Graduates 2012 database, where the number of the initiated contacts is 32 on average. Concerning this, on the average, five contacts have been made by employers, as in the case of social pedagogy professionals, and becoming employed in the first post-graduate job lasts for four months (3.93) (Veroszta, 2013). Regarding the control groups, it can be said that among the social workers $(\mathrm{N}=126)$ the same results were obtained as graduates tried to contact 28 employers on average and the employers contacted them five times on average. After acquiring the final certificate, $25.4 \%$ of them were employed in one month, and other $53.2 \%$ could start work after a longer search with an average duration of four months (4.22). Besides the two social science courses, the data of the arts and humanities group $(\mathrm{N}=152)$ show a more unfavourable image as the respondents reported an average 
of 56 employers to contact and they were contacted at eight times on average. $19.9 \%$ of the respondents found a job within a month. An additional 55.0\% were looking for a job for a longer period which meant half a year (6.32) on average. The results of the graduates of andragogy and pedagogy are not surprising, as according to the analysis by Veroszta (2013), arts and humanities are one of the training fields where graduates can reach the first job through more attempt.

As a conclusion, it can be stated that $82.2 \%$ of the job-seeking social pedagogy graduates, $78.6 \%$ of social worker graduates and $74.9 \%$ of the graduates in the humanities group were able to find a job after obtaining the final certificate $\left(\mathrm{N}_{-}\right.$total=295). Figure 1 shows that the majority of social pedagogy professionals (35.8\%) reached their first job by applying for an employer (e.g. by sending the CV). However, in the case of the other two helping groups, the job application was dominated when applying for the job. It should be emphasised that in the case of the examined trainings, contrary to the whole sample (Veroszta, 2013), no one was employed through an institutional career office/job fair, through a teacher recommendation and nobody started as an entrepreneur/selfemployed person. Furthermore, based on the national data, the role of personal contacts has a stronger emphasis on social sciences compared to the average (Veroszta, 2013; Veroszta, 2015, Veroszta, 2016). This is less common among helping professions. When interpreting the differences, it has to be taken into account that the social status of the individual has a differentiating effect on the network resources (Pusztai, 2011).

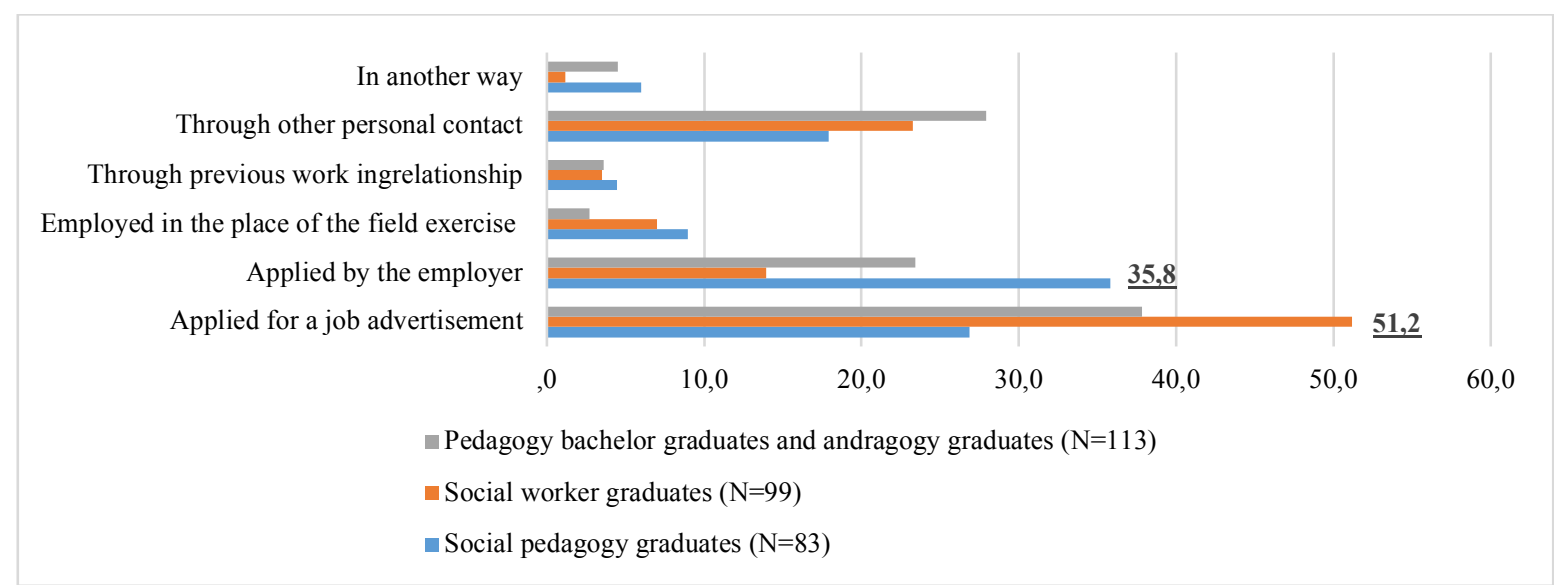

Figure 1. Their ways of attaining the first job after receiving the final certificate (\%). Source: Graduates 2012. Notification: The correlation was significant at $p<0.05$ level $(p=0.020)$. In the case of the underlined values, the absolute value of the adjusted residual is higher than two.

Focusing on the life path of the entire sample (N_total=562), it should be emphasised that since the completion of the qualification, half of the fresh graduate social pedagogy professionals $(50.4 \%)$ and social workers (49.7\%) have already been unemployed at least once while this ratio is higher among andragogy and pedagogy graduates (58.2\%). A similarity can be observed among the three groups, that of graduates typically having only one unemployed period; however, this lasted for eight months on average in the group of social pedagogy professionals while it meant nine months on average among the graduates belonging to the field of social work and humanities. As an explanation, it can be mentioned that although the higher educational degrees obtained in certain fields of training in social sciences and humanities owned a high value (prestige) in the 1990s. However, the labour market became more and more saturated (Györgyi, 2010), and consequently, the employment chances of the fresh graduates decreased and the qualifications were depreciated (Balogh, 2011). At the same time, the data reported by the Hungarian Central Statistical Office (KSH) in Quarter 1 of 2016 drew attention to the steady increase in labour demand, which showed outstanding value in the field of human health and social care $(3.2 \%)(\mathrm{KSH}, 2016)$. 


\section{The current situation of the labour market}

Figure 2 shows the labour market status of the fields. At the time of the study, the majority of the social pedagogy professionals $(78.2 \%)$ were brought on as employees, which provides a higher ratio compared to the social workers (66.8\%) and the group of andragogy and pedagogy professionals (54.4\%). However, the proportion of graduates among the two humanities groups who studied in full-time training (20.9\%) is significantly higher than that of the other two groups.

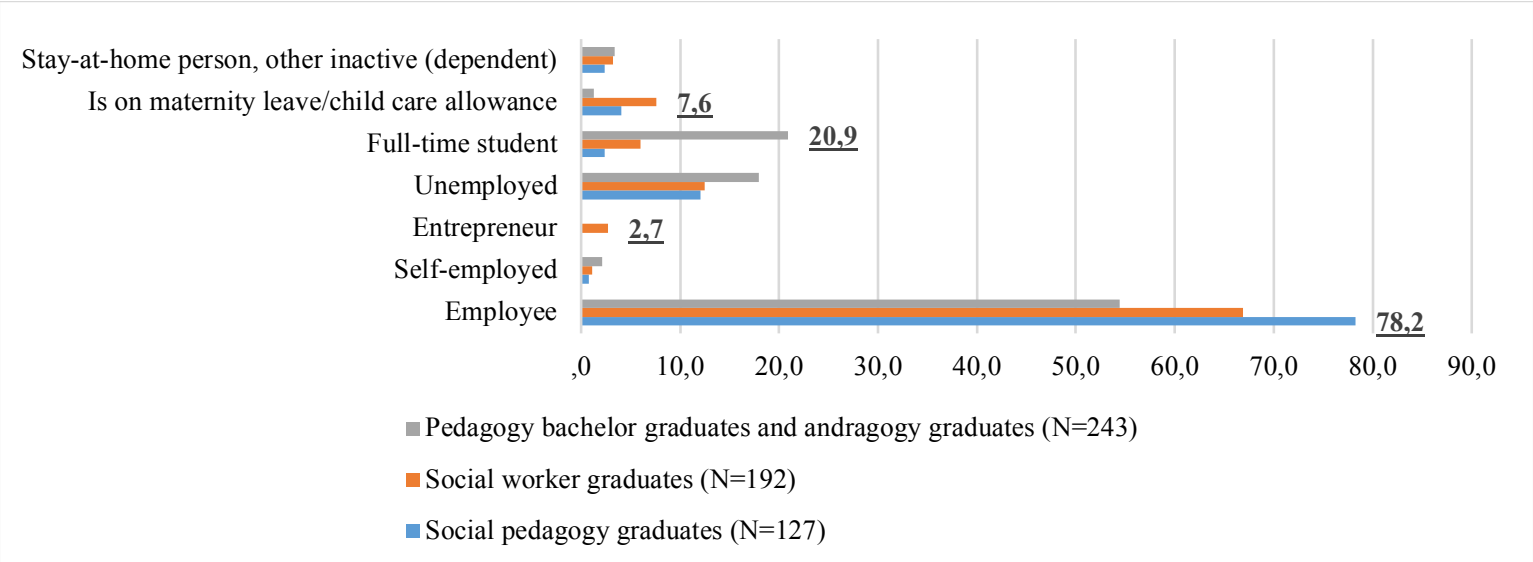

Figure 2. The actual labour-market status of the graduates (\%). Source: Graduates 2012.

Notification: The correlation was significant at $\mathrm{p}<0.05$ level $(\mathrm{p}=0.000)$. In the case of the underlined values, the absolute value of the adjusted residual is higher than two.

Figure 2 also shows that $12.1 \%$ of social pedagogy professionals, $12.5 \%$ of social workers and $18.0 \%$ of andragogy and pedagogy professionals reported an unemployment period as well, which surpasses the unemployment ratio provided by all of the respondents of the Graduates 2012 database $(6.5 \%)$. The proportion of unemployment is higher among the graduates of social sciences and humanities although it still does not reach $10 \%$ (Veroszta, 2013). Thus, it can be stated that the trainings investigated in our research, taking into account the specificities of the fields as well, had less favourable indicators in the examined period.

Further questions (fit to qualification and income) were concerned to those who worked at the time of the study (N_total=379). In terms of fitting, Veroszta (2013) analyses the relationship between study field and work (horizontal fit) and the congruence between the level of education and occupation (vertical fit) in a graduate career tracking study.

Based on our results shown in Figure 3, in terms of horizontal fit, only $4.1 \%$ of social pedagogy professionals indicated that their own field of study suited the best to their job, however, $68.0 \%$ said their own and related specialties fit to their job. Among social workers, compared to the other two groups, the proportion of those judging that only the specialty of their studies corresponds to the job is higher (18.7\%) (Adj.Resid.=4.9). Among the andragogy and pedagogy graduates, 31.2\% report that a completely different field fits in the best way while $15.2 \%$ thought that any field would fit the job. Our results are consistent with previous research experiences. In his empirical analyses, Polónyi (2004) found that higher horizontal incongruence is more common among those having a college level social and humanities qualification. Accordingly, Balogh (2011) considers the low intensity of professional-specific knowledge to be the most characteristic in the field of humanities, but also in the field of social science. Focusing on social pedagogy experts and considering the problem of professional-specific knowledge, Szöllősi (2017) also drew attention to the fact that many of the jobs that can be filled with this qualification correspond to several other vocational qualifications. Several investigations have also pointed out the horizontal incongruity of the professionals of the humanities (Szerepi, 2006; Veroszta, 2013; Veroszta, 2016) and one of the possible reasons was thought to be the low demand and prestige of their profession in the study by Bognár and Péntek (2011). 


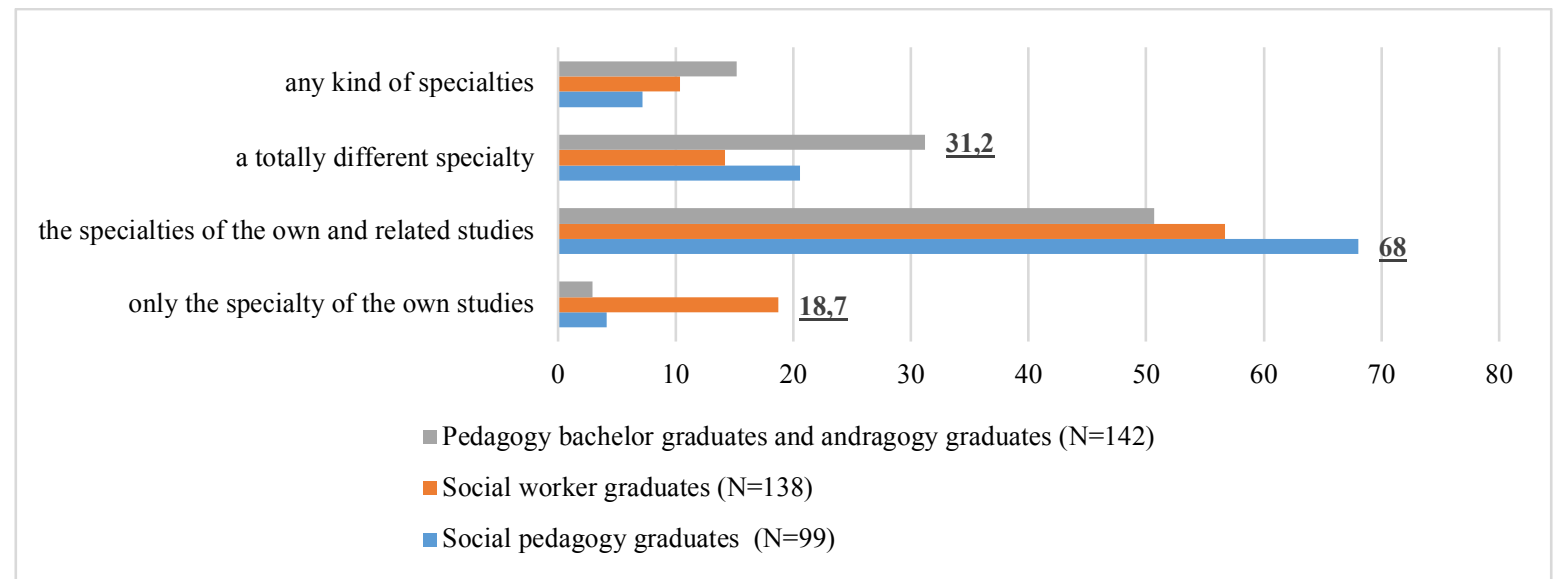

Figure 3. What kind of specialisation fit the best to your job (\%)? Source: Graduates 2012.

Notification: The correlation was significant at $p<0.05$ level $(p=0.000)$. In the case of the underlined values, the absolute value of the adjusted residual is higher than two.

Figure 4 shows data on vertical fit: $28.9 \%$ of social pedagogy professionals, $23.7 \%$ of social workers, $41.3 \%$ of the group of andragogy and pedagogy professionals say that their work does not require a higher educational certificate at all. According to the analysis of Veroszta (2013), $18.5 \%$ of the employed in the follow-up study of 2012 thought that their work did not require higher educational certificate. Thus, it can be stated in the examined groups that vertical incongruence was higher, especially in the group of humanities, focusing on those whose job did not require tertiary educational level (Adj.Resid.=3.1).

no higher educational certificate is required for the job college certificate/BA/BSc degree university certificate/MA/MSc degree other postgraduate training $\mathrm{PhD}$
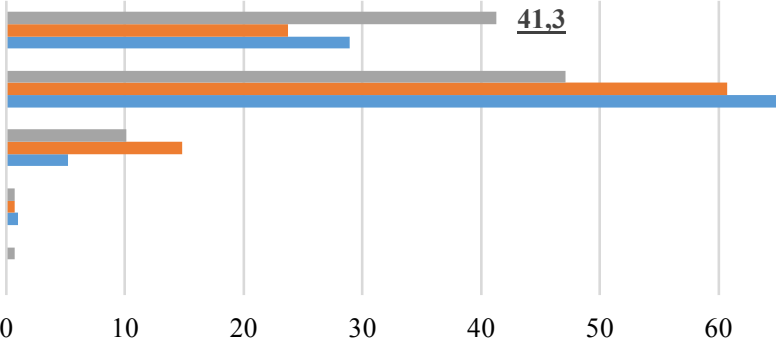

- Pedagogy bachelor graduates and andragogy graduates $(\mathrm{N}=142)$

- Social worker graduates $(\mathrm{N}=138)$

- Social pedagogy graduates $(\mathrm{N}=99)$

Figure 4. What level of education fits the best for your job (\%)? Source: Graduates 2012.

Notification: The correlation was significant at $p<0.05$ level $(p=0.025)$. In the case of the underlined values, the absolute value of the adjusted residual is higher than two.

Examining the average net monthly salary of the full-time employees of the three groups, the lowest salary among social pedagogy experts (103,000 HUF), followed by andragogy and pedagogical bachelor professionals (118,000 HUF) and the highest among social workers $(122,000$ HUF). However, the examined groups are all below the earnings of the fresh graduates of the Career Tracking Survey 2012, where the net monthly salary was 174,000 HUF on average for all respondents (including those working abroad), while the average of those working in Hungary was 159,700 HUF (Veroszta, 2013). In terms of helping careers, the proportion of those who work abroad is negligible $(6.2 \%)$, but when separating them, the average net monthly salary was the lowest still among social pedagogy professionals in our study (100,000 HUF), followed by the andragogy and pedagogy bachelor professionals (108,000 HUF), then by social workers (112,000 HUF). 


\section{Conclusions}

The generalisation of our research results is limited by the circumstances of the quantitative data collection and the dynamic internal changes of the higher educational system. Our goal is to extend the analysis to other career tracking databases and to get feedback on graduates of helping careers and the formation of the labour market needs in the field by large-sample qualitative research. The practical conclusion drawn from our research results can be based on the observation that graduates of theory-centred training highlighted the difficulties of placement. Therefore, based on previous student feedback, even if we are talking about stochastic and non-deterministic relationships, it may be worth to place greater emphasis on curriculum development, including the synthesis of theory and practice and the promotion of self-employment. It can, therefore, be concluded that there is a need for the coordination of the social function of the individual qualifications and the structure of the training. Changes have happened within andragogy while the education policy and content reform of the pedagogy bachelor training have not been occurred yet. In contrast, social pedagogy and social worker professionals pointed out the problems after being employed (e.g. low income), which would be supported by top-down actions, increasing the attractiveness and retention of these paths in the long term (Csók, 2020a).

Funding: Project no. 123847 has been implemented with the support provided by the National Research, Development and Innovation Fund of Hungary, financed under the K-17 funding scheme.

Acknowledgments: Supported by the ÚNKP-18-2 New National Excellence Program of the Ministry of Human Capacities.

Conflicts of Interest: The author declares no conflict of interest.

\section{References}

1. Balogh, E., Budai, I., Goldmann, R., Puli, E. \& Szöllősi, G. (2015). Felsőfokú szociális képzések Magyarországon. [Higher social education in Hungary] Párbeszéd, 2, 1-98.

2. Balogh, G. (2011). A lehetőségek áttekintése gazdasági perspektívából. [An overview of opportunities from an economic perspective] Gazdaságetika, 2(3), 1-12.

3. Benkő, B. (2009). Szociálpedagógia szakos hallgatók a felsőoktatásban és a munkaerő-piacon. [Students learning Social Pedagogy in Higher Education and in the Labor Market] Debrecen: Debreceni Egyetem.

4. Bognár, A. \& Péntek, E. (2011). Mit ér a pécsi bölcsészdiploma - hallgatói szemmel. [What is the art certificate - in the student perspective] Acta Sociologica - Pécsi Szociológiai Szemle, 4(1), 173-182.

5. Budai, I. (2014). Képzés a szociális munkában - szociális munka a képzésben. [Training in Social Work Social Work in Training] Párbeszéd, 1(1-2), 1-13.

6. Csók, C. (2020a). Diplomások szakmai szocializációja szociális és pedagógiai segítő pályákon. [Professional socialization of graduates in social and pedagogical careers] In Juvenilia VIII. Debrecen: Debreceni Egyetemi Kiadó. Expected to be published in 2020 Spring.

7. Csók, C. (2020b). The social recruitment basis of the helping professionals. In InterTalent UNIDEB. Debrecen: Debreceni Egyetem. Expected to be published in 2020 Spring.

8. Fónai, M. (2010). A jogi és igazgatási képzési területen végzettek elhelyezkedésének presztízs szempontjai. [Prestige of graduates in legal and administrative training] In Garai, O., Horváth, T., Kiss, L., Szép, L. \& Veroszta, Zs. (Eds.). Diplomás pályakövetés IV. Frissdiplomások 2010. [Graduate Tracking IV. New Graduates 2010] Budapest: Educatio Társadalmi Szolgáltató Nonprofit Kft. Felsőoktatási Osztály. 227-244.

9. Gáti, A. (2010). Társadalmi háttér és mobilitás. [Social background and mobility] In Garai, O., Horváth, T., Kiss, L., Szép, L. \& Veroszta, Zs. (Eds.). Diplomás pályakövetés IV. Frissdiplomások 2010. [Graduate Tracking IV. New Graduates 2010] Budapest: Educatio Társadalmi Szolgáltató Nonprofit Kft. Felsőoktatási Osztály. 155176.

10. Györgyi, Z. (2010). Munkaerő-piaci esélyek, munkaerő-piaci stratégiák. [Labor market opportunities, labor market strategies] In Garai, O., Horváth, T., Kiss, L., Szép, L. \& Veroszta, Zs. (Eds.). Diplomás pályakövetés IV. Frissdiplomások 2010. [Graduate Tracking IV. New Graduates 2010] Budapest: Educatio Társadalmi Szolgáltató Nonprofit Kft. Felsőoktatási Osztály. 37-58. 
11. Hegedűs, R. (2016). Számok - arányok - mintázatok a felsőoktatásba felvett hátrányos helyzetüek esetében. [Numbers - ratios - patterns for disadvantaged people in higher education] Modern Geográfia, 10(3), 1-14.

12. Hrubos, I. (2011). A diverzifikált felsőoktatási rendszer értelmezése Európában. [Interpreting a diversified higher education system in Europe] In Berács, J., Hrubos, I. \& Temesi, J. (Eds.). „Magyar Felsőoktatás 2010”. Konferencia dokumentumok. ['Hungarian Higher Education 2010'. Conference documents] Budapest: BCE KK, NFKK. 87-90.

13. Kertesi, G. \& Köllő, J. (2006). Felsőoktatási expanzió, „diplomás munkanélküliség” és a diplomák piaci értéke. [Expansion of higher education, 'graduate unemployment' and the market value of diplomas] Közgazdasági Szemle, 53(3), 201-225.

14. Kiss, L. (2013). Alacsony státuszú" szakok az alapképzésben. ['Low status' courses in Bachelor training] In Garai, O. \& Veroszta, Zs. (Eds.). Frissdiplomások 2011. [Graduates 2011] Budapest: Educatio Társadalmi Szolgáltató Nonprofit Kft. Felsőoktatási Osztály. 67-91.

15. Kiss, Zs. (2015). Fiatal magyar diplomások foglalkoztathatósága. [The employability of young Hungarian graduates] In Pusztai, G. \& Kovács, K. (Eds.). Ki eredményes a felsőoktatásban? [Who is successful in higher education?] Nagyvárad-Budapest: Partium Könyvkiadó-Personal Problems Solution-Új Mandátum Könyvkiadó. 55-65.

16. Kleisz, T. (2005). A népmúvelés és a szociális munka szakmásodása angolszász és magyar metszetekben. [Specialisation in folk education and social work in Anglo-Saxon and Hungarian sections] Debrecen: Debreceni Egyetem.

17. KSH (2016). Statisztikai tükör. Betöltésre váró álláshelyek, 2016. I. negyedév. [Statistical mirror. Jobs to be fulfilled, first quarter of 2016] http://www.ksh.hu/docs/hun/xftp/stattukor/uresallas161.pdf

18. Márkus, E. (2016). Amikor a harmadik az első. A civil szektor többféle nézópontból. [When the third is the first. The civil sector is from different perspectives] Debrecen: Csokonai Kiadó.

19. Molnár, N. (2014). Segítő szakmák felsőoktatási differenciálódása Magyarországon. [Differenciation of helping professions in higher education] In Karlovitz, J. T. (Ed.). Kulturális és társadalmi sokszínüség a változó gazdasági környezetben. [Cultural and social diversity in the changing economic environment] Komárno: International Research Institute. 294-301.

20. N. Tóth, Á. (2011). Munka és tanulás vs. pedagógus életpálya. [Work \& Learning vs. teacher career] In N. Tóth, Á. (Ed.). Változó professzió, változó tanárképzés. [Changing professions, changing teacher training] Szombathely: Savaria University Press. 331-360.

21. N. Tóth, Á. (2014). Mérföldkövek a pedagógussá válás folyamatában - empirikus kutatás a Nyugatmagyarországi Egyetemen végzett pedagógusok körében. [Milestones in the process of becoming a teacher - empirical research among teachers at the University of West Hungary] Magyar Pedagógia, 114(1), 25-48.

22. Nagy, K. (2008): Segítô hivatásokat választó hallgatók pályaorientációja a "Partiumban". [Career orientation of students choosing helping profession in 'Partium'] Debrecen: Debreceni Egyetem.

23. Polónyi, I. (2004). A felsőoktatás és a gazdasági szféra kapcsolata-egy empirikus vizsgálat. [The relationship between higher education and the economic sphere - an empirical study.] marketing.pte.hu/sites/marketing.pte.hu/files/files/feo_vallalat_polonyi.doc

24. Pusztai, G. (2006). Egy határmenti régió hallgatótársadalmának térszerkezete. [Spatial structure of the student community of a border region.] In Juhász, E. (Ed.). Régió és oktatás. A "Regionális egyetem" kutatás zárókonferenciájának tanulmánykötete. [Region and education. Book of the Final Conference of the Regional University Research] Debrecen: Doktoranduszok Kiss Árpád Közhasznú Egyesülete. 43-57.

25. Pusztai, G. (2011). A láthatatlan kéztól a baráti kezekig. Hallgatói értelmezö közösségek a felsőoktatásban. [The invisible hand to the hands of friends. Student Interpreting Communities in Higher Education] Budapest: Új Mandátum Könyvkiadó.

26. Pusztai, G. (2015). Tanulmányi eredményességet támogató tényezők az egyetem falain belül és kívül. [Supporting factors of academic achievement inside and outside the university] In Pusztai, G. \& Kovács, K. (Eds.). Ki eredményes a felsőoktatásban? [Who is successful in higher education?] Nagyvárad-Budapest: Partium Könyvkiadó-Personal Problems Solution-Új Mandátum Könyvkiadó. 79-96.

27. Pusztai, G., Bocsi, V. \& Ceglédi, T. (2016). A felsőoktatás hozzáadott értéke Közép-európai kontextusban. [Added value of higher education in a Central European context] In Pusztai, G., Bocsi, V. \& Ceglédi, T. (Eds.). A felsőoktatás (hozzáadott) értéke. Közelitések az intézményi hozzájárulás empirikus megragadásához. [The added value of higher education. Approximations to grab the contribution of the institution empirically] NagyváradBudapest: Partium Könyvkiadó-Personal Problems Solution-Új Mandátum Könyvkiadó. 7-12. 
28. Róbert, P. (1986). Származás és mobilitás. Rétegződés-modell vizsgálat VII. [Origin and mobility. Study of Layout Model VII] Budapest: Társadalomtudományi Intézet.

29. Róbert, P. (2000). Bővülő felsőoktatás: ki jut be? [Expanding Higher Education: Who Will Get In?] Educatio, 9(1), 79-94.

30. Szerepi, A. (2006). Munkaadók és fejvadászok a munkaerőpiacról és az oktatási rendszerről. [Employers and headhunters on the labour market and educational system] In Györgyi, Z. (Ed.). Diplomával a munkaerópiacon. [With a certificate in the labour market] Budapest: Felsőoktatási Kutatóintézet. 91-114.

31. Szöllősi, G. (2017). Szociális munka és szociálpedagógia - tudományos diskurzusok, kutatási területek. [Social work and social pedagogy - scientific discourses, research areas] In Nagy, Á. (Ed.). Tizenkilencre lapot? Szociálpedagógia a XXI. században. [Social pedagogy in the 21st century] Kecskemét: Pallasz Athéné Egyetem - Iuvenis Ifjúságszakmai Mühely, ISZT Alapítvány. 80-103.

32. Temesváry, Zs, (2010). A szociális szakképzések helyzete a mai magyar felsőoktatásban. [The situation of social vocational training in today's Hungarian higher education] Kapocs, 9(1), 34-41.

33. Teperics, K. (2005). Debrecen oktatási vonzáskörzete. [Educational attraction of Debrecen] In Czimre, K. (Ed.). Kisközségtól az eurorégióig. [From small communities to euroregion] Debrecen: Didakt Kiadó. 58-71.

34. Veroszta, Zs. (2013). Frissdiplomások 2012. Kutatási zárótanulmány - Diplomás Pályakövetési Rendszer országos kutatás. [Graduates 2012. Final Research Study - Graduate Career Tracking System national research] Budapest: Educatio Nonprofit Kft. Felsőoktatási Osztály.

35. Veroszta, Zs. (2015). Frissdiplomások 2014. Kutatási zárótanulmány - Diplomás Pályakövetési Rendszer országos kutatás. [Graduates 2014. Final Research Study - Graduate Career Tracking System national research] Budapest: Educatio Nonprofit Kft. Felsőoktatási Osztály.

36. Veroszta, Zs. (2016). Frissdiplomások 2015. Kutatási zárótanulmány - Diplomás Pályakövetési Rendszer országos kutatás. [Graduates 2015. Final Research Study - Graduate Career Tracking System national research] Budapest: Oktatási Hivatal Felsőoktatási Elemzési Főosztály.

(C) 2020 by the author. Submitted for possible open access publication under the terms and conditions of the Creative Commons Attribution (CC BY) license (http://creativecommons.org/licenses/by/4.0/). 